\title{
Postharvest Calcium Infiltration Alone and Combined with Surface Coating Treatments Influence Volatile Levels, Respiration, Ethylene Production, and Internal Atmospheres of 'Golden Delicious'Apples
}

\author{
Robert A. Saftner and William S. Conway \\ U.S. Department of Agriculture, Agricultural Research Service, Horticultural Crops Quality Laboratory, \\ Beltsville Agricultural Research Center, Beltsville, MD 20705 \\ Carl E. Sams \\ Department of Plant and Soil Science, The University of Tennessee, Knoxville, TN 37901
}

ADDITIONAL INDEX wORDs. Malus sylvestris var. domestica, shellac, wax

\begin{abstract}
Effects of postharvest pressure infiltration of distilled water, $\mathrm{CaCl}_{2}$ solutions at 0.14 or $0.27 \mathrm{~mol} \cdot \mathrm{L}^{-1}$ without and with subsequent fruit coating treatments of preclimacteric 'Golden Delicious' [Malus sylvestris (L.) Mill. var. domestica (Borkh.) Mansf. 'Golden Delicious'] apples on volatile levels, respiration, ethylene production, and internal atmospheres after storage at $0{ }^{\circ} \mathrm{C}$ for 1 to 6 months, and during subsequent shelf life at $20{ }^{\circ} \mathrm{C}$ were investigated. Over 30 volatiles were detected, most of the identified volatiles were esters; the rest were alcohols, aldehydes, ethers, a ketone, and a sesquiterpene. Pressure infiltration of water and increasing concentrations of $\mathrm{CaCl}_{2}$ resulted progressively in reduced total volatile levels, respiration, ethylene production, and internal $\mathrm{O}_{2}$ levels and increased $\mathrm{CO}_{2}$ levels in fruit following 2 to 4 months storage in air at $0^{\circ} \mathrm{C}$. Total volatile levels, respiration, ethylene production, and internal atmospheres of $\mathrm{CaCl}_{2}$-treated apples at 0.14 mol $\cdot \mathrm{L}^{-1}$ gradually recovered to nontreated control levels following 2 weeks of shelf life at $20^{\circ} \mathrm{C}$ and/or storage at $0{ }^{\circ} \mathrm{C}$ in air for more than 4 months. Following the calcium treatments with a shellac- or wax-based coating had similar but stronger and more persistent effects on volatile levels, respiration, ethylene production, and internal atmospheres than those found in fruit treated with $\mathrm{CaCl}_{2}$ alone. Calcium infiltration did not change the composition of volatile compounds found in fruit. Results suggest that pressure infiltration of 'Golden Delicious' apples with $\mathbf{C a C l}_{2}$ solutions transiently inhibited volatile levels, respiration, and ethylene production, in part, by forming a more-or-less transient barrier to $\mathrm{CO}_{2}$ and $\mathrm{O}_{2}$ exchange between the fruit tissue and the surrounding atmosphere.
\end{abstract}

Increasing the Ca content of apples has been shown to alleviate physiological storage disorders (Yuen, 1994), reduce losses due to decay-causing fungi (Conway et al., 1991) and maintain fruit firmness and quality (Mason et al., 1975). Calcium chloride is naturally occurring, inexpensive, edible and has been approved by the U.S. Food and Drug Administration for postharvest use (Yuen 1994). While the commercial benefits of postharvest application of $\mathrm{Ca}$ are enticing, the technology has not been widely adopted due, in part, to the inability to predict potential injury (e.g., lenticel pitting and surface discoloration) to the fruit. Recently, peel injury has been shown to be significantly reduced (or eliminated) by application of osmotically balanced $\mathrm{CaCl}_{2}$ solutions followed by surface coating the fruit to reduce fresh weight loss and to maintain tissue water relations during subsequent storage at $0^{\circ}$ or $20^{\circ} \mathrm{C}$ (Saftner et al., 1998).

Both postharvest application of $\mathrm{Ca}$ and surface coating treatments can also reduce respiration (Bangerth et al., 1972; Faust and Shear, 1972), ethylene production (Conway and Sams, 1987; Lougheed et al., 1979), internal $\mathrm{O}_{2}$ levels (Hewett and Thompson, 1992; Rajapakse et al., 1992) and increase internal $\mathrm{CO}_{2}$ levels (Hewett and Thompson, 1992; Saftner et al., 1998). Other treat-

Received for publication 25 Sept. 1998. Accepted for publication 29 May 1999. Use of a company name or product by the U.S. Department of Agriculture does not imply approval or recommendation of the product to the exclusion of others that also may be suitable. We thank Michele Auldridge for dedicated technical help and for statistical analyses of the data and Jerry D. Cohen for use of his gas chromatograph-mass spectrometer and for helpful suggestions on interpretation of mass spectral data. The cost of publishing this paper was defrayed in part by the payment of page charges. Under postal regulations, this paper therefore must be hereby marked advertisement solely to indicate this fact. ments known to inhibit respiration and ethylene production rates and to modify the internal atmospheres of apples have a transient to persistent inhibitory effect on volatile production (Brackmann et al., 1993; Halder-Doll and Bangerth, 1987; Kester and Fennema, 1986; Knee and Sharples, 1981), the factor considered most likely responsible for diminished apple flavor (Knee and Hatfield, 1981; Smith, 1984). Postharvest injection of $\mathrm{CaNO}_{3}$ solution into the core of apples has been shown to nonsignificantly inhibit quality-associated volatile production (Wills, 1972). More recently, infiltration of high osmotic concentrations of $\mathrm{CaCl}_{2}$-mannitol solutions into climacteric apples inhibited volatile production during subsequent storage at $20^{\circ}$ or $4^{\circ} \mathrm{C}$ (Song and Bangerth, 1993).

To our knowledge, the effect of $\mathrm{CaCl}_{2}$ infiltrations alone and in combination with surface coating treatments of preclimacteric apples on quality-associated volatile levels during subsequent storage at $0^{\circ}$ and $20^{\circ} \mathrm{C}$ has not been reported. The objective of this study was to examine whether postharvest $\mathrm{Ca}$ application without and with surface coating treatments of preclimacteric 'Golden Delicious' (Malus sylvestris var. domestica 'Golden Delicious') apples besides extending shelf life also affects quality-associated volatile production.

\section{Materials and Methods}

'Golden Delicious' apples (100 count per box size) were harvested in the preclimacteric stage (ethylene production $\left\langle 2 \mathrm{pmol} \cdot \mathrm{kg}^{-1} \cdot \mathrm{s}^{-1}\right.$ and the climacteric rise in $\mathrm{CO}_{2}$ production had not yet begun; starch index 3.3 using Cornell generic starch chart scale 1 to 8 (Blanpied and Silsby, 1992); firmness $<85 \mathrm{~N}$ ) from a commercial orchard (Rice Bros., Biglerville, Pa.) and randomized. Within $2 \mathrm{~d}$ after harvest, fruit were 
pressure infiltrated ( $3 \mathrm{~min}$ at $103 \mathrm{kPa}$ ) with distilled water or $\mathrm{CaCl}_{2} \cdot 2 \mathrm{H}_{2} \mathrm{O}$ solutions of 0.14 or $0.27 \mathrm{~mol} \cdot \mathrm{L}^{-1}$. Following infiltration, fruit were rinsed by dipping for $\approx 10 \mathrm{~s}$ in distilled water at $20 \pm$ $1{ }^{\circ} \mathrm{C}$ before drying. Rinsed fruit in 120 -fruit sets were either handcoated $(0.4 \mathrm{~mL}$ per fruit) to simulate uniform commercial applications with a shellac- or wax-based formulation or left uncoated. The wax coating was selected for its relatively high permeability for $\mathrm{CO}_{2}$ and $\mathrm{O}_{2}$ and low permeability for water vapor (Hagenmaier and Shaw, 1992) and volatiles. It was prepared by R. Hagenmaier, U.S. Dept. of Agriculture, Agricultural Research Service, Winter Haven, Fla.; and its exact composition was candelilla wax (16.7\%), isopropyl alcohol (2-propanol; 8.0\%), morpholine (2.1\%), oleic acid (cis9-octadecanoic acid; $1.3 \%$ ), and the remainder as water. The shellac coating (Apple Lustr 221, Elf Atochem/Decco, Monrovia, Calif.) was selected as representative of apple coatings used commercially to enhance outward appearance, e.g., increased gloss. It is reported to contain water, shellac, fatty acid soaps, fast-drying solvents, and other minor ingredients. Treated and nontreated (control) fruit were then stored at $0{ }^{\circ} \mathrm{C}$ in air for $1,2,3,4,4.5,5$, or 6 months.

Respiration and ethylene production rates of treated and nontreated fruit were monitored every $6 \mathrm{~h}$ during a $7-\mathrm{d}$ period at $20^{\circ} \mathrm{C}$ using an automated system (Izumi et al., 1996). Two five-fruit replications were measured at monthly intervals from harvest through 6 months of cold storage. Results for $\mathrm{CO}_{2}$ and ethylene produced are both reported as nmol $\cdot \mathrm{kg}^{-1} \cdot \mathrm{s}^{-1}$.

At the end of $1-\mathrm{d}$ at $20^{\circ} \mathrm{C}$ following 0 to 6 months cold storage, fruit cavity $\mathrm{CO}_{2}$ and $\mathrm{O}_{2}$ levels were determined by inserting a steel hypodermic needle into the cavity through the calyx region of individually submerged fruit, then drawing 6-mL samples with a gas-tight syringe. Gas samples from five or 10 identically treated fruit were analyzed from each storage period. The levels of $\mathrm{CO}_{2}$ and $\mathrm{O}_{2}$ were measured using a gas chromatograph (GC) (model GC3BT; Shimadzu, Kyoto, Japan) fitted with Porapak Q and Molecular Sieve 5 A columns (each $\approx 2 \mathrm{~m} \times 3 \mathrm{~mm}$ ) and a thermal conductivity detector. The levels of ethylene were determined with a GC (model AGC-211; Carle, Tulsa, Okla.) fitted with an alumina column (2 m $\times 3 \mathrm{~mm}$ ) and photoionization detector.

Fresh weight loss, Ca content, and quality attributes of firmness and volatile levels were determined on the same sets of treated and nontreated fruit. The fresh weight of 40-fruit sets of treated and nontreated fruit were measured at harvest and again at monthly intervals between 1 and 6 months cold storage. Fruit firmness was measured on 20-fruit sets with a manually controlled digital penetrometer (EPT-1 with an 11.1-mm tip; Lake City Technical Products, Kelowna, B.C., Canada) set in the Magness-Taylor mode as described previously (Saftner et al., 1998).

Preparation of fruit tissue for $\mathrm{Ca}$ content analyses was as described previously (Saftner et al., 1997). Prepared samples were analyzed for $\mathrm{Ca}$ content by inductively coupled plasma emission spectroscopy (model 61E; Thermo Jarrell Ash, Franklin, Mass.). Calcium content is reported on a dry weight basis (in mmol $\mathrm{kg}^{-1}$ ). Each sample consisted of the flesh from six or seven apples, and four samples were obtained from each treatment.

For volatile analyses, juice from nonpeeled slices of individual fruit from each treatment was hand extracted using a crimping tool to resemble normal tissue mastication, i.e., chewing of an apple. Saturated $\mathrm{CaCl}_{2}$ was not added to the apple extracts to inhibit enzymatic activities associated with volatile biosynthesis (Buttery and Ling, 1993). Adding salts to the samples variably accelerated volatilization of sample analytes and induced quantitative and qualitative changes in the apple volatile profiles that are unlikely to occur during normal tissue mastication (R. Saftner, unpublished data). One milliliter of each extract was transferred to a 4-mL vial and capped with a teflon-lined septum. The samples were quick frozen to $-20{ }^{\circ} \mathrm{C}$ and stored for up to 1 week before volatile collection. Preliminary results indicated that volatile levels were the same in crude extracts and extracts clarified by centrifugation or filtration and did not change over a 1-month storage period at -20 ${ }^{\circ} \mathrm{C}$. For volatile sampling, frozen samples were thawed and equilibrated for $5 \mathrm{~min}$ at $20^{\circ} \mathrm{C}$. A solid-phase microextraction (SPME, SupelcoCo., Bellefonte, $\mathrm{Pa}$.) fiber coated with polydimethylsiloxane (PDMS, $1 \mathrm{~cm}$ long, $100 \mathrm{~mm}$ thick) was used to collect and concentrate volatiles by virtue of its sorption characteristics (Arthur and Pawliszyn, 1990). The SPME device consisted of the retractable fiber enclosed in a metal needle. During sampling, after entering the 4-mL vial, the fiber was manually extended, volatile sorption occurred for $16 \mathrm{~min}$, then the fiber was retracted before removal from the sampling vial. The sorbed volatiles were desorbed from the fiber for $2 \mathrm{~min}$ at $250^{\circ} \mathrm{C}$ into a glass-lined, splitless injection port of a GC (5890a Series II; Hewlett Packard Co., Rockville, Md.) equipped with electronic pressure control and a flame ionization detector (FID), which was used to measure relative volatile vapor levels.

Apple volatiles were separated and identified using a procedure similar to that of Song et al., 1997). Volatiles were separated using a capillary column $(\mathrm{HP}-5,11 \mathrm{~m} \times 0.1 \mathrm{~mm}$ id., $0.34 \mathrm{~mm}$ coating thickness). The carrier gas was ultra purified hydrogen (6.0 research) at a flow velocity of $52 \mathrm{~cm} \cdot \mathrm{s}^{-1}$. The temperature program was isothermal for $2 \mathrm{~min}$ at $40^{\circ} \mathrm{C}$ and then raised at the rate of $30^{\circ} \mathrm{C} \cdot \mathrm{min}^{-1}$ to $250{ }^{\circ} \mathrm{C}$, and held for $3 \mathrm{~min}$. Injector and detector port temperatures were both $250{ }^{\circ} \mathrm{C}$. Volatile levels are reported in relative FID area response units; calibration factors were not determined, as only relative changes were of interest. Preliminary results indicated that PDMS fibers never approached saturation during headspace sampling. Samples for volatile analyses were collected from treated and nontreated fruit after $1 \mathrm{~d}$ at $20^{\circ} \mathrm{C}$ following 0 to 6 months cold storage and at weekly intervals during 3 weeks at $20^{\circ} \mathrm{C}$ following 4.5 and 6 months cold storage. All SPME sampling was carried out 10 times at $20^{\circ} \mathrm{C}$ for each treatment and for each storage and shelf life.

For volatile identification, a GC/mass spectrometer (MS) procedure was used. The GC procedure was the same as described above except that ultra purified helium was used as the carrier gas. The GC/ MS transfer line temperature was $250{ }^{\circ} \mathrm{C}$. Volatile detection was performed by quadrupole MS using $70 \mathrm{eV}$ electron impact ionization (5971A, Hewlett Packard Co., Rockville, Md.). Mass spectra were collected over a range of $\mathrm{m} / \mathrm{z} 40$ to 300. Identification of volatile components was confirmed by comparison of collected mass spectra with those of standards and spectra in the National Institute for Standards and Technology (NIST) mass spectral library, Search Version C.01.00 (Aldrich, Milwaukee, Wis.).

Harvests were made from the same commercial orchard in 1996 and 1997. In the first year of experimentation, fruit volatile levels were not determined. In the second year, all treatments described above were made and only results from the second year are reported since overlapping results from both years were similar.

Data were analyzed using mixed model analysis of variance procedures (SAS Institute, Cary, N.C.). Examination of variance heterogeneity among the treatments indicated that the random experimental variance should be partitioned into two or three experimental variances. In most cases, the experimental variance was pooled for nontreated and water-treated fruit, $\mathrm{CaCl}_{2}$-treated fruit at 0.14 or $0.27 \mathrm{~mol} \cdot \mathrm{L}^{-1}$, and $\mathrm{CaCl}_{2}$ plus coated (shellac and wax) fruit. Group comparisons and factoral interactions were evaluated 
by contrasts. The likelihood ratio test indicated that fitting the experimental variances into two or three groups was better than models for a single variance. Examination of residuals for both the two and three variance models did not indicate any concern regarding normality. Treatment means were separated at $P<0.05$ using Tukey's multiple comparison test. Unless stated otherwise, only results significant at $P<0.05$ are discussed.

\section{Results}

Pressure infiltration of $\mathrm{CaCl}_{2}$ solutions used in this study effectively increased the internal Ca levels of Ca-treated fruit. The mean $\pm \mathrm{SE}$ level of internal $\mathrm{Ca}$ in nontreated fruit was $7.2 \pm 0.3 \mathrm{mmol} \cdot \mathrm{kg}^{-1} \mathrm{dry}$ weight. In water-infiltrated and $\mathrm{CaCl}_{2}$-infiltrated fruit at 0.14 or 0.27 $\mathrm{mol} \cdot \mathrm{L}^{-1}$, the internal Ca levels were $7.9 \pm 0.5,30.5 \pm 1.7$, and 48.0 $\pm 1.9 \mathrm{mmol} \cdot \mathrm{kg}^{-1}$ dry weight, respectively.

Volatiles, mostly esters, were detected in the headspace above extracts of nontreated 'Golden Delicious' apples (Table 1). The rest of the identified volatiles were alcohols, aldehydes, a ketone, a sesquiterpene, and ethers. Pressure infiltration of $\mathrm{CaCl}_{2}$ solutions resulted in reduced total volatile levels between 2 and 4 months storage (Fig. 1). Beyond 4 months storage, both water- and $\mathrm{Ca}$ treated fruit had the same or higher total volatile levels as those in the corresponding nontreated fruit. The two concentrations of $\mathrm{CaCl}_{2}$ used in this study had a similar effect on total volatile levels during cold storage. Sequential treatments with a $\mathrm{CaCl}_{2}$ solution of 0.14 $\mathrm{mol} \cdot \mathrm{L}^{-1}$ and a fruit coating had a more persistent inhibitory effect on total volatile levels than treatment with the $\mathrm{CaCl}_{2}$ solution alone. Individual straight chain (Fig. 2A, butyl acetate) and branched chain (Fig. 2B, 2-methylbutyl acetate) volatiles followed the same pattern of change during cold storage as those of total volatile levels. Most of the volatile compounds present at lower levels than those shown in Fig. 2 followed the same pattern or change during cold storage (data not shown). Total and most individual volatile levels peaked in nontreated fruit following 3 months cold storage. All treated and nontreated fruit contained essentially the same or higher individual and total volatile levels following various periods of cold storage than those present at harvest (Figs. 1 and 2). Fruit treated with $\mathrm{CaCl}_{2}$

Table 1. Volatile compounds in the headspace above extracts collected from nontreated 'Golden Delicious' apples after $1 \mathrm{~d}$ at $20^{\circ} \mathrm{C}$ following 3 months storage in air at $0{ }^{\circ} \mathrm{C}$.

\begin{tabular}{|c|c|c|c|c|}
\hline Peak & $\begin{array}{l}\text { Volatile } \\
\text { compound }\end{array}$ & $\begin{array}{l}\text { Retention } \\
\text { ratio }^{z}\end{array}$ & $\begin{array}{c}\text { GC-FID } \\
\times 10^{3}\end{array}$ & $\begin{array}{c}\text { Percent of } \\
\text { total } \\
\text { GC-FID } \\
\text { response }\end{array}$ \\
\hline 1 & Ethanol & 0.13 & $<1$ & 0.1 \\
\hline 2 & Ethyl acetate & 0.26 & $<1$ & 0.1 \\
\hline 3 & 1-Butanol & 0.34 & $<3$ & 0.6 \\
\hline 4 & Propyl acetate & 0.48 & $<1$ & 0.1 \\
\hline 5 & Unknown & 0.57 & $<2$ & 0.4 \\
\hline 6 & 2-Methylpropyl acetate & 0.71 & $<3$ & 0.6 \\
\hline 7 & Hexanal & 0.79 & $15-24$ & 4.6 \\
\hline 8 & Butyl acetate & 0.84 & $57-79$ & 16.4 \\
\hline 9 & trans-2-Hexenal & 0.93 & $10-14$ & 2.8 \\
\hline 10 & Ethyl 2-methylbutyrate & 0.96 & $<1$ & 0.1 \\
\hline 11 & 1-Hexanol & 0.98 & $8-14$ & 2.7 \\
\hline 12 & 2-Methylbutyl acetate & 1.00 & $40-65$ & 12.6 \\
\hline 13 & Propyl butyrate & 1.04 & $<1$ & 0.1 \\
\hline 14 & Unknown & 1.05 & $<1$ & 0.2 \\
\hline 15 & Butyl propionate & 1.06 & $4-6$ & 1.2 \\
\hline 16 & Pentyl acetate & 1.08 & $5-7$ & 1.5 \\
\hline 17 & Butyl 2-methylbutyrate & 1.14 & $<1$ & 0.1 \\
\hline 18 & 6-Methyl-5-hepten-2-one & 1.21 & $<2$ & 0.4 \\
\hline 19 & Butyl butyrate & 1.23 & $15-23$ & 4.6 \\
\hline 20 & Hexyl acetate & 1.26 & $90-131$ & 26.6 \\
\hline 21 & Butyl 2-methylbutyrate & 1.31 & $19-26$ & 5.4 \\
\hline 22 & Butyl pentanoate & 1.39 & $<1$ & 0.1 \\
\hline 23 & Pentyl butyrate & 1.41 & $<2$ & 0.4 \\
\hline 24 & Butyl hexanoate + Hexyl butyrate & 1.54 & $26-39$ & 7.7 \\
\hline 25 & 4-Allylanisole & 1.56 & $<3$ & 0.7 \\
\hline 26 & Hexyl 2-methylbutyrate & 1.60 & $7-12$ & 2.3 \\
\hline 27 & Unknown & 1.67 & $<1$ & 0.1 \\
\hline 28 & Hexyl pentanoate & 1.68 & $<1$ & 0.1 \\
\hline 29 & Propyl octanoate & 1.78 & $<1$ & 0.1 \\
\hline 30 & Hexyl hexanoate & 1.80 & $4-6$ & 1.2 \\
\hline 31 & Unknown & 1.81 & $<3$ & 0.6 \\
\hline 32 & Unknown & 1.90 & $<1$ & 0.1 \\
\hline 33 & o-Methoxybenzene & 1.91 & $<1$ & 0.1 \\
\hline 34 & $\alpha$-Farnesene & 1.96 & $17-24$ & 4.9 \\
\hline
\end{tabular}

Retention time of volatile relative to retention time of 2-methylbutyl acetate. 


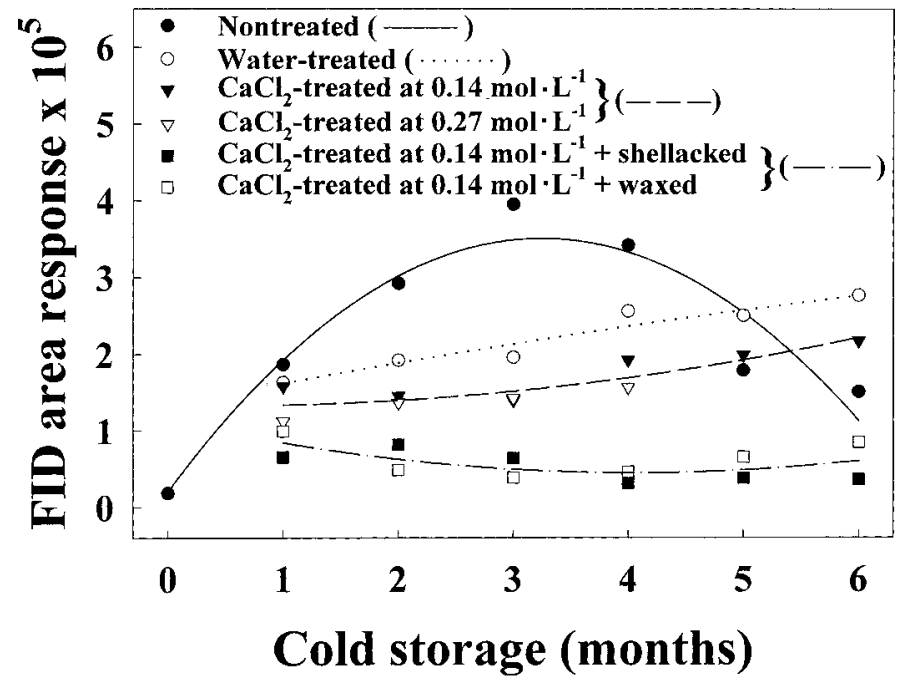

Fig. 1. Effect of water and $\mathrm{CaCl}_{2}$ treatments, alone and followed by coating treatments, on total volatile levels in the headspace of extracts collected from 'Golden Delicious' fruit after a 1 -d period at $20^{\circ} \mathrm{C}$ following 0 to 6 months storage in air at $0^{\circ} \mathrm{C}$. Each symbol is the mean of 10 readings collected from 10 individual fruit extracts. Nonlinear regression lines are for data collected from nontreated, water-treated, $\mathrm{CaCl}_{2}$-treated $\left(0.14\right.$ and $\left.0.27 \mathrm{~mol} \cdot \mathrm{L}^{-1}\right)$, and $\mathrm{CaCl}_{2}+$ coated (shellac and wax) fruit; $R^{2}$ were $0.90,0.92,0.96$, and 0.94 , respectively, and the sEs of the estimate were $0.49 \times 10^{5}, 0.16 \times 10^{5}, 0.08 \times 10^{5}$, and $0.04 \times 10^{5}$, respectively.

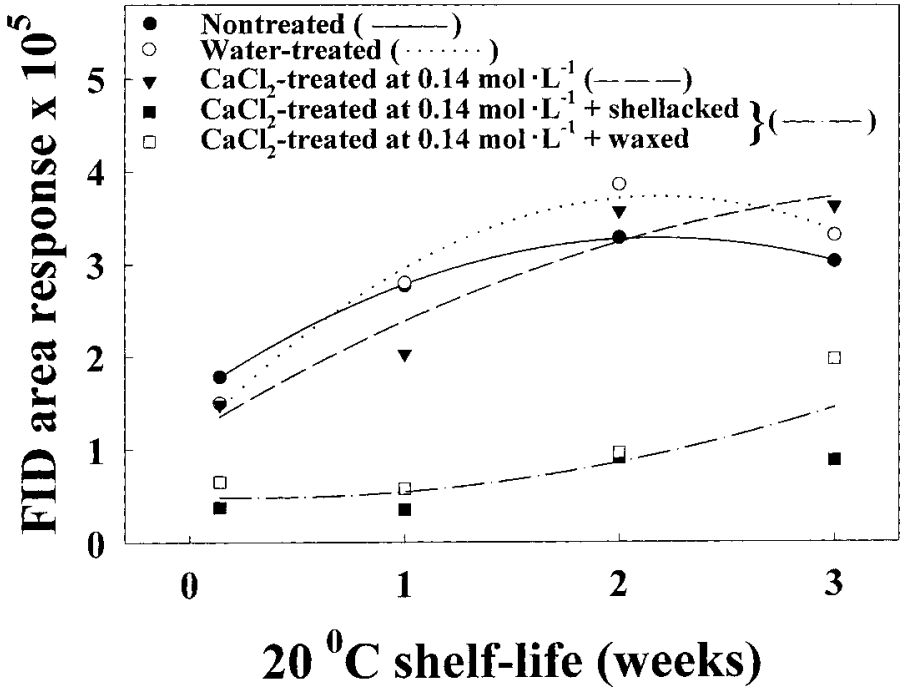

Fig. 3. Effect of water and $\mathrm{CaCl}_{2}$ treatments, alone and followed by coating treatments, on total volatile levels in the headspace of extracts collected from 'Golden Delicious' apples during a 1-d to 3 -week holding period at $20^{\circ} \mathrm{C}$ following 4.5 months storage in air at $0{ }^{\circ} \mathrm{C}$. Each symbol is the mean of 10 readings from 10 individual fruit extracts. Nonlinear regression lines are for data collected from nontreated, water-treated, $\mathrm{CaCl}_{2}$ treated $\left(0.14\right.$ and $\left.0.27 \mathrm{~mol} \cdot \mathrm{L}^{-1}\right)$, and $\mathrm{CaCl}_{2}+$ coated (shellac and wax) fruit; $R^{2}$ were 0.99 , $0.98,0.93$, and 0.98 , respectively, and the SES of the estimate were $0.42 \times 10^{5}, 0.23 \times 10^{5}$, $0.51 \times 10^{5}$, and $0.11 \times 10^{5}$, respectively.

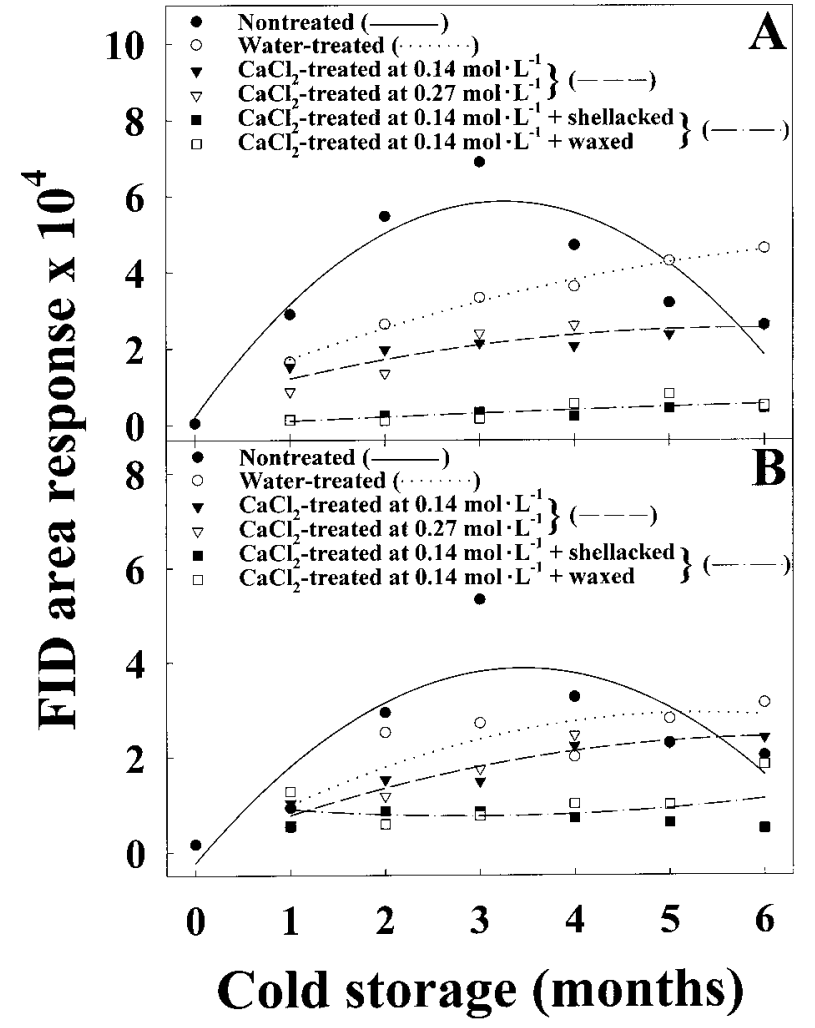

Fig. 2. Effect of water and $\mathrm{CaCl}_{2}$ treatments, alone and followed by coating treatments on (A) butyl acetate and (B) 2-methylbutyl acetate levels in the headspace of extracts collected from 'Golden Delicious' apples after a 1-d period at $20^{\circ} \mathrm{C}$ following 0 to 6 months storage in air at $0{ }^{\circ} \mathrm{C}$. Each symbol is the mean of 10 readings from 10 individual fruit extracts. Nonlinear regression lines are for data collected from nontreated, watertreated, $\mathrm{CaCl}_{2}$-treated $\left(0.14\right.$ and $\left.0.27 \mathrm{~mol} \cdot \mathrm{L}^{-1}\right)$, and $\mathrm{CaCl}_{2}+$ coated (shellac and wax) fruit. For Fig. 2A regression lines, $R^{2}$ were $0.87,0.99,0.96$, and 0.81 , respectively, and the SES of the estimate were $0.98 \times 10^{4}, 0.14 \times 10^{4}, 0.14 \times 10^{4}$, and $0.10 \times 10^{4}$, respectively. For Fig. $2 \mathrm{~B}$ regression lines, $R^{2}$ were $0.75,0.86,0.96$, and 0.78 , respectively, and the SES of the estimate were $1.03 \times 10^{4}, 0.71 \times 10^{4}, 0.17 \times 10^{4}$, and $0.09 \times 10^{4}$, respectively.

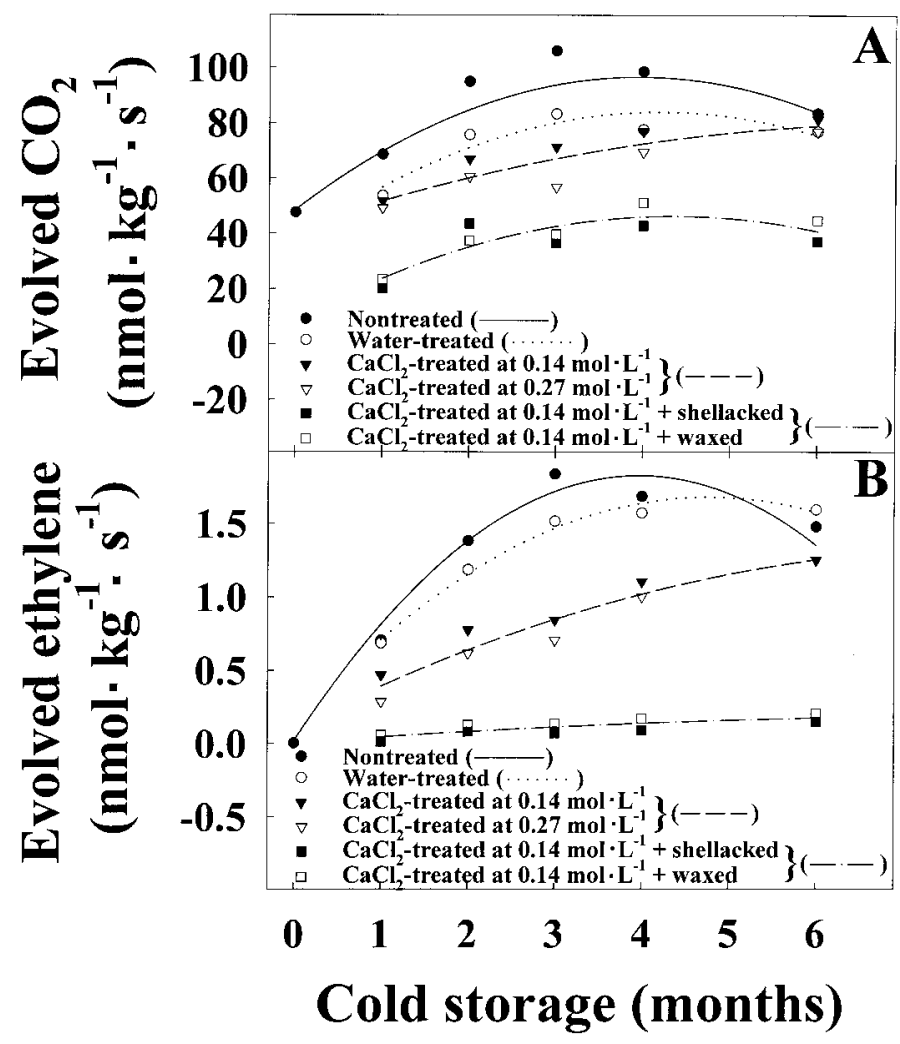

Fig. 4. Effect of water and $\mathrm{CaCl}_{2}$ treatments, alone and followed by coating treatments, on evolved (A) carbon dioxide and (B) ethylene production rates in 'Golden Delicious' apples during a 7 -d period at $20^{\circ} \mathrm{C}$ following 0 to 6 months storage in air at $0^{\circ} \mathrm{C}$. Each symbol is the mean of 48 readings from two five-fruit replications. Nonlinear regression lines are for data collected from nontreated, water-treated, $\mathrm{CaCl}_{2}$-treated $(0.14$ and 0.27 mol. $\mathrm{L}^{-1}$ ), and $\mathrm{CaCl}_{2}+$ coated (shellac and wax) fruit. For Fig. 4A regression lines, $R^{2}$ were $0.90,0.84,0.95$, and 0.85 , respectively, and the sEs of the estimate were $8,6,3$, and 5 , respectively. For Fig. 4B regression lines, $R^{2}$ were $0.98,0.94,0.98$, and 0.93 , respectively, and the SES of the estimate were $0.11,0.07,0.07$, and 0.02 , respectively. 
Table 2. Internal carbon dioxide and oxygen levels of 'Golden Delicious' apples after $1 \mathrm{~d}$ at $20^{\circ} \mathrm{C}$ following 1 to 6 months storage in air at $0^{\circ} \mathrm{C}$.

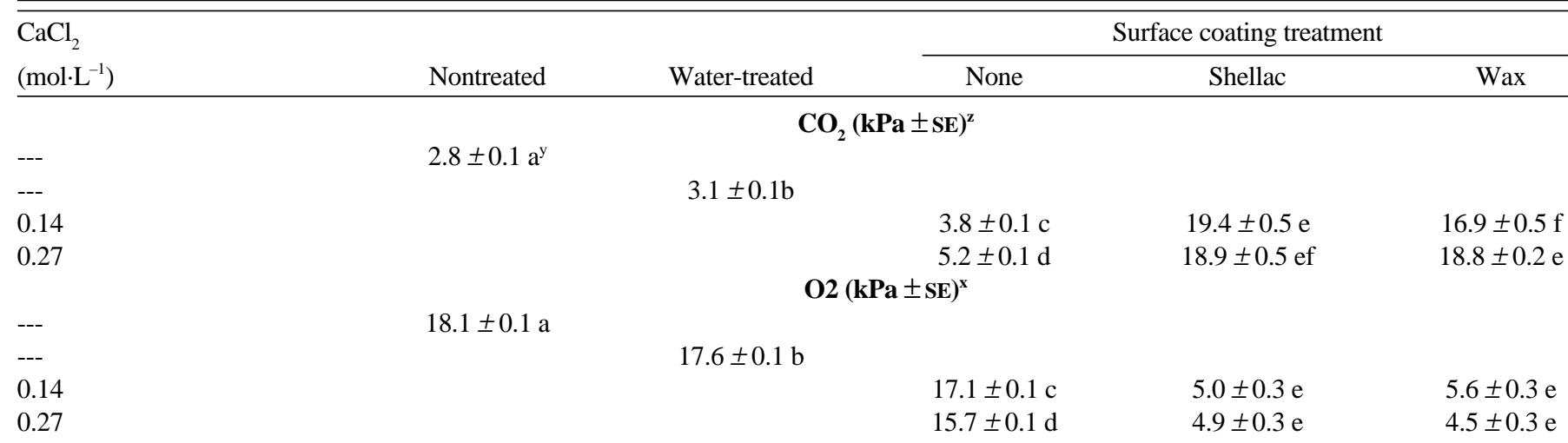

${ }^{\mathrm{z}}$ Significant group contrasts: nontreated and water-treated vs. $\mathrm{CaCl}_{2}$-treated $(P=0.0001) ; \mathrm{CaCl}_{2}$-treated at $0.14 \mathrm{vs} .0 .28 \mathrm{~mol} \cdot \mathrm{L}^{-1}(P=0.0046) ;$ noncoated vs. coated $(P=0.0001)$; shellac vs. wax $(P=0.0060) ; \mathrm{CaCl}_{2}$ vs. $\mathrm{CaCl}_{2}+$ coated $(P=0.0002)$.

${ }^{y}$ All data are reported as the mean \pm SE of 30 atmospheric readings from 30 individual fruit. Means for each gas followed by the same letter are not significantly different by Tukey's multiple comparison test $(P<0.05)$.

${ }^{x}$ Significant group contrasts: nontreated and water-treated vs. $\mathrm{CaCl}_{2}$-treated $(P=0.0001) ; \mathrm{CaCl}_{2}$-treated at $0.14 \mathrm{vs} .0 .28 \mathrm{~mol} \cdot \mathrm{L}^{-1}(P=0.0001) ;$ noncoated vs. coated $(P=0.0001) ; \mathrm{CaCl}_{2}$ vs. $\mathrm{CaCl}_{2}+$ coated $(P=0.0001)$.

at $0.27 \mathrm{~mol} \cdot \mathrm{L}^{-1}$ and stored at $0{ }^{\circ} \mathrm{C}$ for $>4$ months developed surface injury and were not used for volatile analyses.

Total volatile levels increased similarly in nontreated, water- and $\mathrm{CaCl}_{2}$-infiltrated fruit during a 3 -week shelf life at $20^{\circ} \mathrm{C}$ following storage at $0^{\circ} \mathrm{C}$ for 4.5 months (Fig. 3 ) or 6 months (data not shown). Total volatile levels increased at a slower rate in fruit sequentially treated with $\mathrm{CaCl}_{2}$ at $0.14 \mathrm{~mol} \cdot \mathrm{L}^{-1}$ and a fruit coating than in nontreated fruit or fruit treated with $\mathrm{CaCl}_{2}$ alone (Fig. 3).

Total and most individual volatile levels in treated and nontreated fruit followed similar transient to persistent reductive trends (Figs. 1 and 2) during cold storage as those for respiration (Fig. 4A) and ethylene production (Fig. 4B) in corresponding treated and nontreated fruit. Pressure infiltration of increasing concentrations of $\mathrm{CaCl}_{2}$ resulted progressively in increased internal $\mathrm{CO}_{2}$ and decreased internal $\mathrm{O}_{2}$ levels following 1 to 6 months cold storage (Table 2). Fruit treated sequentially with $\mathrm{CaCl}_{2}$ solutions and a surface coating had higher $\mathrm{CO}_{2}$ and lower $\mathrm{O}_{2}$ levels following 1 to 6 months cold storage than those in nontreated fruit and fruit treated with $\mathrm{CaCl}_{2}$ alone. During cold storage, the internal $\mathrm{CO}_{2}$ and $\mathrm{O}_{2}$ levels of fruit sequentially treated with $\mathrm{CaCl}_{2}$ and a surface coating were $18.3 \pm 0.1$ (SE) and $5.0 \pm 0.1 \mathrm{kPa}$, respectively.

Besides transiently reducing total volatile levels, respiration, and ethylene production, $\mathrm{CaCl}_{2}$ treatments delayed ripening; as indicated by better retention of flesh firmness. Following 6 months cold storage, flesh firmness was $51.8 \pm 1.2 \mathrm{~N}$ in nontreated fruit; $60.1 \pm 1.4 \mathrm{~N}$ and $63.0 \pm 2.1 \mathrm{~N}$ in $\mathrm{CaCl}_{2}$-treated fruit at 0.14 and $0.27 \mathrm{~mol} \cdot \mathrm{L}^{-1}$, respectively; and 67.2 $\pm 1.1 \mathrm{~N}$ and $68.1 \pm 1.5 \mathrm{~N}$ in shellacked and waxed fruit treated with $\mathrm{CaCl}_{2}$ at $0.14 \mathrm{~mol} \cdot \mathrm{L}^{-1}$, respectively.

\section{Discussion}

Calcium, as its chloride salt, has great potential as a postharvest shelf-life-extending treatment for apples. In this study, pressure infiltration of $\mathrm{CaCl}_{2}$ solutions at 0.14 or $0.27 \mathrm{~mol} \cdot \mathrm{L}^{-1}$ effectively increased the $\mathrm{Ca}$ content of the fruit to levels that did or are known to maintain flesh firmness (Mason et al., 1975), retard postharvest decay caused by pathogens (Biggs et al., 1993; Conway et al., 1991), decrease the incidence of physiological disorders, and extend the postharvest life of the fruit (Yuen, 1994). However, other postharvest treatments that extend shelf life have been reported to reduce volatile levels (Brackmann et al., 1993; Halder-Doll and Bangerth,
1987), the factor most likely responsible for diminished apple flavor (Knee and Hatfield, 1981; Smith, 1984).

The qualitative composition of volatiles in our studies using headspace analyses of apple extracts (Table 1) was similar to that found by other investigators using intact apple headspace or vacuum distillation methods (Dimick and Hoskin, 1983; Mattheis et al., 1998; Paillard, 1990; Song et al., 1997). However, the headspace of 'Golden Delicious' apple extracts contained hexanal and trans-2hexenal, volatiles not generally observed in intact mature and ripening apples. These aldehydes are formed rapidly during tissue mastication and other tissue disruption treatments (Paillard, 1986) such as those used to prepare juice extracts in this study and are among the most important components of apple-like odor in 'Delicious' apples (Flath et al., 1967). Most of the other volatiles identified in the headspace of 'Golden Delicious' apple extracts have sweet, fruity, apple-like and/or spicy odors (Aldrich Chemical Co., 1997) and are generally considered to contribute to the overall flavor of the fruit.

Pressure infiltration of 'Golden Delicious' apples with water or Ca solutions markedly but only transiently reduced total volatile levels, specific straight- and branched-chain volatile levels, respiration, ethylene production, internal $\mathrm{O}_{2}$ levels, and increased internal $\mathrm{CO}_{2}$ of the fruit following 1 to 6 months storage in air at $0{ }^{\circ} \mathrm{C}$. Sequential $\mathrm{CaCl}_{2}$ and surface coating treatments had more persistent effects on volatile levels, internal atmospheres, and ripening-related characteristics of apples than treatment with $\mathrm{CaCl}_{2}$ solutions alone.

The above results may be explained, in part, by the tendency of infiltrated solutions to form temporary and surface coatings to form more-or-less permanent barriers to the exchange of $\mathrm{CO}_{2}$ and $\mathrm{O}_{2}$ between the fruit tissue and the surrounding atmosphere (Banks et al., 1993; Rajapakse et al., 1992). The greater alteration of internal atmospheres by $\mathrm{CaCl}_{2}$ solutions than by water may be due, in part, to the reduced solubility of $\mathrm{CO}_{2}$ and $\mathrm{O}_{2}$ in $\mathrm{CaCl}_{2}$ solutions than in water (Leonard, 1939) and to the tendency of apple cells to sorb more water than $\mathrm{CaCl}_{2}$ thus reducing the level of gas-exchange blockages within the fruit during storage (Rajapakse et al., 1992). In our experiments, the rather strong but similarly transient effect of $\mathrm{CaCl}_{2}$ solutions on modifying internal atmospheres, respiration, ethylene production, and volatile levels indicates that infiltration of $\mathrm{CaCl}_{2}$ solutions probably acts, in part, by transiently blocking gas exchange. This interpretation is supported by findings that modi- 
fication of the internal atmosphere or application of controlled atmospheres at $\mathrm{CO}_{2}$ and $\mathrm{O}_{2}$ concentrations that do not cause physiological disorders also reduce respiration, ethylene production and action, and retard compositional changes associated with fruit firmness, flavor and other quality characteristics (Kader, 1995). The transient nature of the $\mathrm{Ca}$ infiltration-associated effects reported in this study is in contrast to the more persistent inhibitory effects observed by Song and Bangerth (1993) following $\mathrm{CaCl}_{2}$-mannitol infiltrations. While the reason for the differing results is presently unknown, commercial applications of $\mathrm{CaCl}_{2}$ are always done without mannitol addition. In all postharvest $\mathrm{CaCl}_{2}$ infiltrations, factors other than impaired gas exchange must also be active in that $\mathrm{Ca}$ affects membrane structure and functioning, and cell wall structure and functioning, all of which have been associated with the regulation of the ripening process of fruit and maintenance of fruit quality characteristics (Ferguson, 1984).

The possibility that a more general and not a specific change in metabolic activity occurs as a result of $\mathrm{Ca}$ infiltration is supported by the finding that all of the main volatiles measured in this study followed a pattern similar to that of total volatile levels and to that of respiration and ethylene production during cold storage and subsequent shelf life at $20^{\circ} \mathrm{C}$. Results in Fig. 2 for two of the most prominent volatiles of 'Golden Delicious' fruit support this observation. Both straight- and branched-chain volatiles displayed similar patterns of change (see Fig. 2) even though their precursors, fatty acids and amino acids, respectively (Paillard, 1990), originate from different metabolic pathways. This finding is similar to results obtained with 'Golden Delicious' fruit that have been heat treated (Fallik et al., 1997) or surface coated (R. Saftner, unpublished data) at harvest or stored under CA conditions (Brackmann et al., 1993) that delay ripening without inducing physiological disorders and/or the development of off-flavors or odors.

Reduced production of flavor-associated volatiles is a matter of great concern to the apple industry. After a progressively extended storage period, volatile levels in Ca-treated fruit recovered to those present in nontreated fruit and remained so during subsequent shelf life at $20^{\circ} \mathrm{C}$. However, the volatile levels of fruit treated sequentially with $\mathrm{Ca}$ and a surface coating did not fully recover to those present in nontreated fruit during extended cold storage and 3 weeks shelf life at $20^{\circ} \mathrm{C}$, even though surface coating apples is often used commercially to improve outward appearance, e.g., increased gloss. Results herein suggest that $\mathrm{CaCl}_{2}$ infiltration to maintain firmness and other quality characteristics and to control postharvest pathogens would not adversely affect flavor-associated volatile levels when used in conjunction with commercial storage conditions of 4 months or more and a shelf life of several weeks or longer. Fruit infiltrated sequentially with $\mathrm{CaCl}_{2}$ and a surface coating may require longer storage and shelf-life periods or use of more gas permeable coatings than those used in this study for full recovery of flavorassociated volatile production.

\section{Literature Cited}

Aldrich Chemical Company 1997. Flavors and fragrances. Prod. Lit. 033, Aldrich Chem. Co., Milwaukee, Wis.

Arthur, C.L. and J. Pawliszyn. 1990. Solid-phase microextraction with thermal desorption using fused silica optical fibers. Anal. Chem. 62:2145-2148.

Bangerth, F., D.R. Dilley, and D.H. Dewey. 1972. Effect of postharvest calcium treatments on internal breakdown and respiration of apple fruits. J. Amer. Soc. Hort. Sci. 97:679-682.

Banks, N.H., B.K Dadzie, and D.J. Cleland. 1993. Reducing gas exchange of fruits with surface coatings. Postharvest Biol. Technol. 3:269-284.

Biggs, A.R., M. Ingle, and W.D. Solihati. 1993. Control of Alternaria infection of fruit of apple cultivar Nittany with calcium chloride and fungicides. Plant Dis. 77:976-980.

Blanpied, G.D. and K.L. Silsby. 1992. Predicting harvest date windows for apples. Cornell Coop. Ext. Bul. 221

Brackmann, A., J. Streif, and F. Bangerth. 1993. Relationship between a reduced aroma production and lipid metabolism of apples after long-term controlled-atmosphere storage. J. Amer. Soc. Hort. Sci. 118:243-247.

Buttery, R.G. and L.C. Ling. 1993. Volatile components of tomato fruit and plant parts: Relationship and biogenesis, p. 23-34. In: R. Teranishi, R. Buttery, and H. Sugisawa (eds.) Bioactive volatile compounds from plants. Amer. Chem. Soc., Washington, D.C.

Conway, W.S. and C.E. Sams. 1987. The effects of postharvest infiltration of calcium, magnesium, or strontium on decay, firmness, respiration, and ethylene production in apples. J. Amer. Soc. Hort. Sci. 112:300-303.

Conway, W.S., C.E. Sams, J.A. Abbott, and B.D. Bruton. 1991. Postharvest calcium treatment of apple fruit provide broad spectrum protection against postharvest pathogens. Plant Dis. 75:620-622.

Dimick, P.S. and J.C. Hoskin. 1983. Review of apple flavor: State of the art. CRC Crit. Rev. Food Sci. Nutr. 18:387-409.

Fallik, E., D.D. Archbold, T.R. Hamilton-Kemp, J.H. Loughrin, and R.W. Collins. 1997. Heat treatment temporarily inhibits aroma volatile compound emission from 'Golden Delicious' apples. J. Agr. Food Chem. 45:4038-4041.

Faust, M. and C.B. Shear. 1972. The effect of calcium on respiration in apples. J. Amer. Soc. Hort. Sci. 97:437-439.

Ferguson, I.B. 1984. Calcium in plant senescence and fruit ripening. Plant Cell Environ. 7:477-489.

Flath, R.A., D.R. Black, D.G. Guadagni, W.H. McFadden, and T.H. Schultz. 1967. Identification and organoleptic evaluation of compounds in Delicious apple essence. J. Agr. Food Chem. 15:29-35.

Hagenmaier, R.D. and P.E. Shaw. 1992. Gas permeability of fruit coating waxes. J. Amer. Soc. Hort. Sci. 117:105-109.

Halder-Doll, H. and F. Bangerth. 1987. Inhibition of autocatalytic $\mathrm{C}_{2} \mathrm{H}_{4}$-biosynthesis by AVG applications and consequences on the physiological behaviour and quality of apple fruits in cool storage. Scientia Hort. 33:87-96.

Hewett, E.W. and C.J. Thompson. 1992. Modification of internal carbon dioxide and oxygen levels in apple fruit by postharvest calcium application and modified atmospheres. Postharvest Biol. Technol. 1:213-219.

Izumi, H., A.E. Watada, and W. Douglas. 1996. Optimum $\mathrm{O}_{2}$ and $\mathrm{CO}_{2}$ atmospheres for storing broccoli florets at various temperatures. J. Amer. Soc. Hort. Sci. 121:127-131.

Kader, A.A. 1995. Regulation of fruit physiology in controlled/modified atmospheres. Acta Hort. 398:59-70.

Kester, J.J. and O.R. Fennema. 1986. Edible films and coatings: A review. Food Technol. 42:47-59.

Knee, M. and S.G.S. Hatfield. 1981. The metabolism of alcohols by apple fruit tissue. J. Sci. Food Agr. 32:593-600.

Knee, M. and R.O. Sharples. 1981. The influence of controlled atmosphere storage on the ripening of apples in relation to quality, p. 341-352. In: P.W. Goodenough and R.K. Atkins (eds.). Quality in stored and processed vegetables and fruit. Academic Press, London.

Leonard, E.R. 1939. Studies in tropical fruits. VI. A preliminary consideration of solubility of gases in relation to respiration. Ann Bot. 3:825-843.

Lougheed, E.C., D.P. Murr, and S.R. Miller. 1979. Effects of calcium and daminozide on ethylene production and softening of apple fruits. Experimentia 35:43-44.

Mason, J.L., J.J. Jasmin, and R.L. Granger. 1975. Softening of 'McIntosh' apples by a postharvest dip in calcium chloride solution plus thickener. HortScience 10:524-525.

Mattheis, J.P., D.A. Buchanan, and J.K. Fellman. 1998. Volatile compounds emitted by 'Gala' apples following dynamic atmosphere storage. J. Amer. Soc. Hort. Sci. 123:426432.

Paillard, N.M.M. 1986. Evolution of the capacity of aldehyde production by crushed apple tissues, during an extended storage of fruits. Proc. 4th Intl. Flavor Conf. Dev. Food Sci. 12:369-378.

Paillard, N.M.M. 1990. The flavour of apples, pears and quinces, p. 1-41. In: I.D. Morton and A.J. MacLeod (eds.). Food flavours. Part C: The flavour of fruits. Elsevier Science, New York.

Rajapakse, N.C.,E.W. Hewett, N.H. Banks, and D.J.Cleland. 1992. Vacuum infiltration with calcium chloride influences oxygen distribution in apple fruit flesh. Postharvest Biol. Technol. 1:221-229.

Saftner, R.A. J.G. Buta, W.S. Conway, and C.E. Sams. 1997. Effect of surfactants on pressure infiltration of calcium chloride solutions into 'Golden Delicious' apples. J. Amer. Soc. Hort. Sci. 122:386-391.

Saftner, R.A., W.S. Conway, and C.E. Sams. 1998. Effects of postharvest calcium and fruit coating treatments on postharvest life, quality maintenance, and fruit-surface injury in ‘Golden Delicious' apples. J. Amer. Soc. Hort. Sci. 123:294-299.

Smith, S.M. 1984. Improvement of aroma of Cox's Orange Pippin apples stored in low oxygen atmospheres. J. Hort. Sci. 59:515-522.

Song, J. and F. Bangerth. 1993. The effect of calcium-infiltration on respiration, ethylene and aroma production of 'Golden Delicious' apple fruits. Acta Hort. 326:131-137.

Song, J., B.D. Gardner, J.F. Holland, and R.M. Beaudry. 1997. Rapid analysis of volatile flavor compounds in apple fruit using SPME and GC/time-of-flight mass spectrometry. J. Agr. Food Chem. 45:1801-1807.

Wills, R.B.H. 1972. Effect of calcium on production of volatiles by apples. J. Sci. Food Agr. 23:1131-1134.

Yuen, C.M.C. 1994. Calcium and fruit storage potential. Austral. Centre Intl. Agr. Res. 50:218-227. 